\title{
Early changes in the CD8 T Cell immunodominance hierarchy in primary HIV infection prior to seroconversion
}

\author{
N Keane*, C Almeida, A Chopra, D Cooper, E Demaine, S Mallal, M John \\ From AIDS Vaccine 2012 \\ Boston, MA, USA. 9-12 September 2012
}

\section{Background}

Identification of the earliest CD8 T-cell responses against HIV may help select critical viral targets for inclusion in an HIV vaccine. We describe changes to the earliest detected CD8 T-cell responses and changes in genetic sequence encoding targeted epitopes in an individual who presented with Fiebig stage II, clade C acute HIV-infection, 27 days after sexual transmission.

\section{Methods}

We examined HLA-restricted CD8 T-cell responses by IFN $\gamma$ ELISpot and HIV Gag, Pol, Nef and Env sequence by 454 deep sequencing over 6 timepoints, from days 27-118 after HIV-transmission. HIV-specific IFN $\gamma$ responses were detected against ten HIV epitopes in Gag, Nef and Env at day 27 post HIV-transmission when the patient's CD4 Tcell count was at a nadir of 224 cells $/ \mu$ l, the plasma HIV RNA $>106$ copies/ml and prior to any detectable p24 antibody.

\section{Results}

Immunodominant responses were detected to the HLA$B * 07: 02$ restricted Env IIRRIRQGL (IL9) epitope and the B*07:02 Gag GPGHKARVL (GL9) epitope (>4000SFU). A detectable but weaker response was observed to HLAB*08 Nef FLKEKGGL (FL8) epitope (1010SFU). These responses declined over subsequent timepoints to 470 and 1630 SFU on day 118 coincident with a $2 \log$ fall in the plasma viral load, a rise in the CD4 T cell count to 533 cells/ $\mu \mathrm{L}$ and antibody seroconversion. The Nef FL8 became the immunodominant response after day 34 . IFN $\gamma$ responses broadened from 10 responses at day 27 to 23 responses by day 118. Analysis of Gag, Nef and Pol

Murdoch University, Perth, Australia

(C) 2012 Keane et al; licensee BioMed Central Ltd. This is an Open Access article distributed under the terms of the Creative Commons Attribution License (http://creativecommons.org/licenses/by/2.0), which permits unrestricted use, distribution, and reproduction in any medium, provided the original work is properly cited. genes by 454 deep sequencing showed no evidence of escape within the targeted epitopes as a cause of their decline over time.

\section{Conclusion}

Early changes in the CD8 T-cell immunodominance hierarchy are apparent in acute HIV-infection prior to seroconversion, including early immunodominant targeting of Env epitopes. Subsequent broadening of the CD8 T-cell response was not associated with CD8 T-cell escape in this case.

Published: 13 September 2012

doi:10.1186/1742-4690-9-S2-P244

Cite this article as: Keane et al:: Early changes in the CD8 T Cell

immunodominance hierarchy in primary HIV infection prior to

seroconversion. Retrovirology 2012 9(Suppl 2):P244. and take full advantage of:

- Convenient online submission

- Thorough peer review

- No space constraints or color figure charges

- Immediate publication on acceptance

- Inclusion in PubMed, CAS, Scopus and Google Scholar

- Research which is freely available for redistribution 